\title{
Preparation of a biosorbent complex (clay particles/Streptococcus thermophilus) to treat polluted water with methylene blue
}

\author{
1, ${ }^{*}$ Hadj Said Aissa, ${ }^{2}$ Moulay Meriem, ${ }^{1}$ Benbeguara Mourad, ${ }^{1}$ Hocine Laredj \\ ${ }^{1}$ Laboratory of Agro-biotechnology and nutrition in semi-arid areas - Faculty of nature and life sciences - University Ibn Khaldoun - BP 78 Zaaroura \\ 14000 Tiaret- Algeria. \\ ${ }^{2}$ Laboratory of hygiene and animal pathology- Institute of Veterinary Sciences - University Ibn Khaldoun Tiaret - Algeria.
}

Correspondence Author: Hadj Said Aissa, Laboratory of agro-biotechnology and nutrition in semi-arid areas - Faculty of nature and life sciences University Ibn Khaldoun - BP 78 Zaaroura 14000 Tiaret- Algeria.

Email: hsaissa25@yahoo.fr

Received date: 20 June 2019, Accepted date: 2 August 2019, Online date: 25 August 2019

Copyright: (c) 2019 Hadj Said Aissa et al., This is an open-access article distributed under the terms of the Creative Commons Attribution License, which permits unrestricted use, distribution, and reproduction in any medium, provided the original author and source are credited.

\begin{abstract}
The research and/or development of new materials, already available and inexpensive, seems interesting, as they will be able to trap water pollutants, in particular dyes that can cause serious harm to the environment. The objective of this study is to develop a complex biosorbent based on the immobilization of Streptococcus thermophilus on suspended clay particles of Maghnia for the purpose of treating water artificially polluted with methylene blue at low concentrations $(\leq 20 \mathrm{mg} / \mathrm{L})$ under the experimental conditions of neutral $\mathrm{pH}$ and an ambient temperature of about $20^{\circ} \mathrm{C}$. The purity of the microbial strain was verified by macroscopic and microscopic controls with Gram coloration, while the purification of the natural clay of Maghnia was made by sedimentation. The results obtained show that the microbial strain grown on M17 agar gives round colonies with cremated white color and small sizes, it is Gram(+), catalase (-) and homo-fermenter. The purification of suspended clay particles by sedimentation, the Stokes Law has made it possible to verify that they are less than $2 \mu \mathrm{m}$ in size. Regarding the biosorption of methylene blue by the biosorbent complex, the results show a rapid removal of the dye, it attains equilibrium after 20 minutes of contact. After on hour the elimination rate varies between 88 and $96 \%$ depending on the initial concentration. The application of kinetic models shows a good correlation between experimental data and those results calculated by the Ho and Mc Kay model whereas the results of Weber and Morris indicate the existence of the formation of a limit layer of the dye on the surface of the biosorbent. As for the equilibrium isothermal models Henry's notes reveal that the concentrations applied in methylene blue are low while the Freundlich model indicates a biosorption of the dye in the form of a poly-layer.
\end{abstract}

Keywords: Biosorbent, Streptococcus thermophilus, clay of Maghnia, methylene blue, kinetics, isotherms

\section{INTRODUCTION}

Pollution is a harmful phenomenon for living beings and the environment, in general. It is mainly due to the development of industrial, technological and agronomic activities. To protect the natural environment from pollution, it is crucial and necessary to limit and/or reduce it, by applying specific preventive measures. These include the pre-treatment of any industrial effluent before its release to a natural environment. The treatments used may be physicochemical and/or microbiological, involving in some cases the use of materials capable of securing the pollutants to be removed.

Dyes are among the most polluting substances in the environment. They are widely used in certain industries, such as paper, textile, pharmacy, agri-food and others. There are over 100,000 varieties of dyes on the market and their global production exceeds one million tons per year [1]. In the effluents of these industries, large quantities of dyes are still present, which makes their treatments indispensable before sending them to a natural environment. In addition to their toxicities, they color the aquatic environment that receives them, thus causing great harm to this medium, by reducing the penetration of light, hence the disruption of microbial and photosynthetic activities [2]. 
In soil, bacteria develop in association with the roots of plants and they can also be adsorbed by inorganic surfaces, such as clays, which in soil play a central role in influencing its structure, its porosity and its trading capacity [3]. There are factors that affect soil bioremediation, such as soil moisture, salinity, oxygen transfer, microbial population and nutrient availability in soil [4]. Microorganisms can attach to solid surfaces by their bioadhesive properties to form a biofilm. Its formation on a solid surface is a complex phenomenon. For this, several steps are necessary where physical, chemical and biological processes are involved [5]. Bacterial growth under natural conditions is mainly in the form of immobilized communities (films, colonies or aggregates) and their activity is often studied from isolated planktonic cells [6].

To decontaminate the water from polluting materials, several treatment techniques have been developed, including coagulation, chemical oxidation, membrane separation, electrochemistry and adsorption techniques considered the most promising. Active coal is one of the most widely used adsorbent materials in water treatment [7]. There is a definite interest in developing very ecological and sustainable clay-based materials for water and wastewater disinfection [8]. Indeed, because natural clays are ecological, several types are currently used effectively in the removal of dyes by adsorption of wastewater [1]. Several authors have cited the use of locally available and inexpensive adsorbents, including biosorbents, to trap dyes. Aspergillus niger biomass is considered a biosorbent capable of removing dyes from an aqueous solution. This biosorption is influenced by the functional groups of the biomass and the chemical structure of the dyes [9]. Muchal fungi have been tested in the treatment of textile effluents [10]. Bacterial strain Bacillus catenulatus JB-022, isolated from polluted soils and ponds, was used in the biosorption of a cationic dye (basic blue 3) and cadmium [11]. In the agri-food sector, there have been economic improvements in whey bioconversion processes by applying cell and enzyme immobilization technology [12]. It is within this framework that this work is conducted to, initially, develop a biosorbent complex based on the immobilization of the Streptococcus thermophilus on clay particles of Maghnia in suspension and in a second step, study its kinetics of removing methylene blue (MB) from water polluted by this dye.

\section{MATERIALS AND METHODS}

\subsection{Clay purification and suspension:}

The suspension of clay particles is obtained from the natural clay of Maghnia (Algeria), after purification by settling it in a glass test tube. Twenty grams of sieved clay through a sieve of $80 \mu \mathrm{m}$, is suspended in a liter of distilled water, stirred for 2 hours and left to rest for 24 hours. Four hundred millilitres of the top part of the supernatant of the suspension of clay particles, which constitutes a colloidal suspension with a corresponding height of $13.6 \mathrm{~cm}$, is then recovered by siphoning. Maghnia's natural clay is part of montmorillonites and its main characteristics are shown in Table 1 [13]. This clay after sedimentation has a specific surface area and a density of $40.51 \mathrm{~m}^{2} / \mathrm{g}$ and $2.49 \mathrm{~g} / \mathrm{cm}^{3}$, respectively [2].

Table1: Chemical analyses in \% weight of the natural clay of Maghnia [13].

\begin{tabular}{|l|l|l|l|l|l|l|l|l|l|l|}
\hline Oxide & $\mathbf{S i O}_{2}$ & $\mathbf{A l}_{2} \mathbf{O}_{3}$ & $\mathbf{F e O}_{3}$ & $\mathbf{C a O}$ & $\mathbf{M g O}$ & $\mathbf{N a}_{2} \mathbf{O}$ & $\mathbf{K}_{2} \mathbf{O}$ & $\mathbf{T i O}_{2}$ & $\mathbf{A s}$ & L.O.I* \\
\hline$\%$ & 69,4 & 14,7 & 1,2 & 0,3 & 1,1 & 0,5 & 0,8 & 0,2 & 0,05 & 11 \\
\hline
\end{tabular}

* Loss on the ignition at $900^{\circ} \mathrm{C}$

\subsection{Re-identification and characterization of Streptococcus thermophiles:}

The bacterial strain Streptococcus thermophilus was isolated from raw goat milk from the western region of Algeria (Oran and Tiaret) and made available to us by the laboratory of applied microbiology at the University of Oran. The strain was activated and purified on MRS medium. It was incubated at $37^{\circ} \mathrm{C}$ for 24 hours to obtain well-isolated colonies [14]. Dilution in liquid medium and by streaks in solid medium, allows the production of a pure culture from a well-separated colony. As for the purity of the strain, it was verified by macroscopic and microscopic checks with Gram staining [3].

\subsubsection{Macroscopic observations:}

The macroscopic observations make it possible to describe bacterial culture on solid and liquid media. On solid medium, the type of colonies is described and the color, the perimeter, the elevation, the shape and the diameter are noted. Whereas, on liquid medium, it is the aspect of micro aerophile culture, which can be particularly interesting in the choice of strain.

\subsubsection{Microscopic observations:}


Microscopic examinations allow defining the cellular morphological aspect, the form and the mode of association by Gram staining.

\subsubsection{Biochemical characteristics:}

\subsubsection{Catalase Test:}

Contacting the bacterial colonies with a few drops of oxygenated water makes it possible to test the activity of catalase. The presence of off-gassing indicates positive action of the Catalase enzyme as it breaks down the hydrogen peroxide into oxygenreleasing water [15].

\subsubsection{Type of fermentation:}

The test makes it possible to assess the type of metabolism by which the carbonaceous substrate is transformed. It consists of highlighting the formation of $\mathrm{CO}_{2}$ gas. It is performed by incubating the strain in an M17 broth containing the Durham bell, which allows the detection of the gas produced. The development of a hetero-fermentative bacterium is manifested by the appearance of the gas in the Durham bell while its absence indicates the presence of a homo-fermentative bacterial strain [16].

\subsection{Preparation of biosorbent complex:}

From the purified clay suspension recovered by siphoning, several suspensions clay at $0.1 \mathrm{~g} / \mathrm{L}$ are prepared by adjusting with distilled water, then mixed for 1 hour with a standardized solution of Streptococcus thermophilus. After centrifugation of these mixtures, the resulting units are washed several times with distilled water to remove unfixed microorganisms and then dried for 24 hours at $110^{\circ} \mathrm{C}$, to inactivate immobilized microorganisms on clay particles, followed by grinding and sieving at $80 \mu \mathrm{m}$, so the complex biosorbent is developed. Indeed, there is a good adhesion of Streptococcus thermophilus on suspended clay particles of Maghnia [3].

\subsection{Dye:}

The dye used in this study is the laboratory methylene blue (CI 52015) of molar mass $373.9 \mathrm{~g} / \mathrm{mol}$ and chemical formula $\mathrm{C}_{16} \mathrm{H}_{18} \mathrm{ClN}_{3} \mathrm{~S} .3 \mathrm{H}_{2} \mathrm{O}$.

\subsection{Biosorption of methylene blue in solution:}

Under constant and moderate agitation at about $220 \mathrm{rpm}$, at near-neutral $\mathrm{pH}$ and the ambient temperature of about $20^{\circ} \mathrm{C}$, solutions in methylene blue at low concentrations $(2.5 ; 5 ; 10$ and $20 \mathrm{mg} / \mathrm{L})$, are brought into contact with the biosorbent prepared at $12.5 \mathrm{mg} / \mathrm{L}$. Samples are collected and centrifuged at $5000 \mathrm{rpm}$ for 15 minutes to determine the optical density of the supernatant at a wavelength of $665 \mathrm{~nm}$ and to deduce the residual concentration in methylene blue, not fixed by the biosorbent, using a calibration curve after a contact time of $5 ; 10 ; 15 ; 20 ; 40$ and 60 minutes. Eq. (1) and (2) allow to calculate at the time t, the rate $\mathrm{R}$ $(\%)$ of removal of methylene blue and the quantity $\mathrm{q}(\mathrm{mg} / \mathrm{g})$ fixed on the biosorbent complex, which is the difference between the initial concentration $\mathrm{C}_{0}(\mathrm{mg} / \mathrm{L})$ and residual concentration $\mathrm{C}(\mathrm{mg} / \mathrm{L})$ of dye at the time $\mathrm{t}$ with respect to the concentration $\mathrm{C}_{\mathrm{b}}(\mathrm{g} / \mathrm{L})$ of biosorbent in the mixture.

$$
\begin{aligned}
R(\%) & =\frac{c_{0}-\mathrm{C}}{C_{0}} \cdot 100 \\
q & =\frac{\mathrm{C}_{0}-\mathrm{C}}{\mathrm{C}_{\mathrm{b}}}
\end{aligned}
$$

\section{RESULTS AND DISCUSSIONS}

\subsection{Size of suspended clay particles:}

The application of the Stokes law, Eq. (3) [17], makes it possible to verify that the size d of suspended clay particles, Eq. (4), is much less than $2 \mu \mathrm{m}$. Assuming that they have a spherical shape and that there is no interaction between them with a laminar fall movement in distilled water.

$$
\mathbf{u}=\frac{\mathrm{h}}{\mathrm{t}}=\frac{\Delta \rho \cdot \mathrm{g}}{18 \eta_{\mathrm{l}}} \cdot \mathrm{d}^{2}
$$

So all the particles of the siphoned supernatant have a diameter $\mathbf{d}$ with the following conditions:

$$
\mathrm{d} \leq \sqrt{\frac{18 . \mathrm{h} . \eta_{1}}{\Delta \text { p.g.t }}}=1,4 \mu \mathrm{m}<2 \mu \mathrm{m}
$$


Rate $(\mathrm{u})$ of fall of clay particles in $\mathrm{m} . \mathrm{s}^{-1}, \mathrm{~h}$ and $\mathrm{t}$ are respectively the height and the time of fall. $\Delta \rho$ is the difference between the density of the particles and that of the distilled water; the acceleration of gravity is $(\mathrm{g})$ and $\eta_{1}$ is the dynamic viscosity of water at $20^{\circ} \mathrm{C}$.

Mineral clays form small particulate suspensions in water with an average diameter of about $2 \mu \mathrm{m}$ and have a lamellar structure (succession of sheets) [18].

\subsection{Macroscopic and microscopic observations:}

Streptococcus thermophilus grown on M17 agar form round colonies with cremated white color and small sizes as shown in Fig. 1. On M17 broth, there is somewhat intense disturbance with deposit at the bottom of the tube, as shown in Fig. 2 . As for the microscopic study of a smear stainable by Gram staining, it shows that the strain is Gram(+) and the bacteria are grouped into pairs or chains, as shown in Fig. 3. Other authors have demonstrated similar observations on the macroscopic and microscopic aspects of this microbial strain $[3,19,20]$.

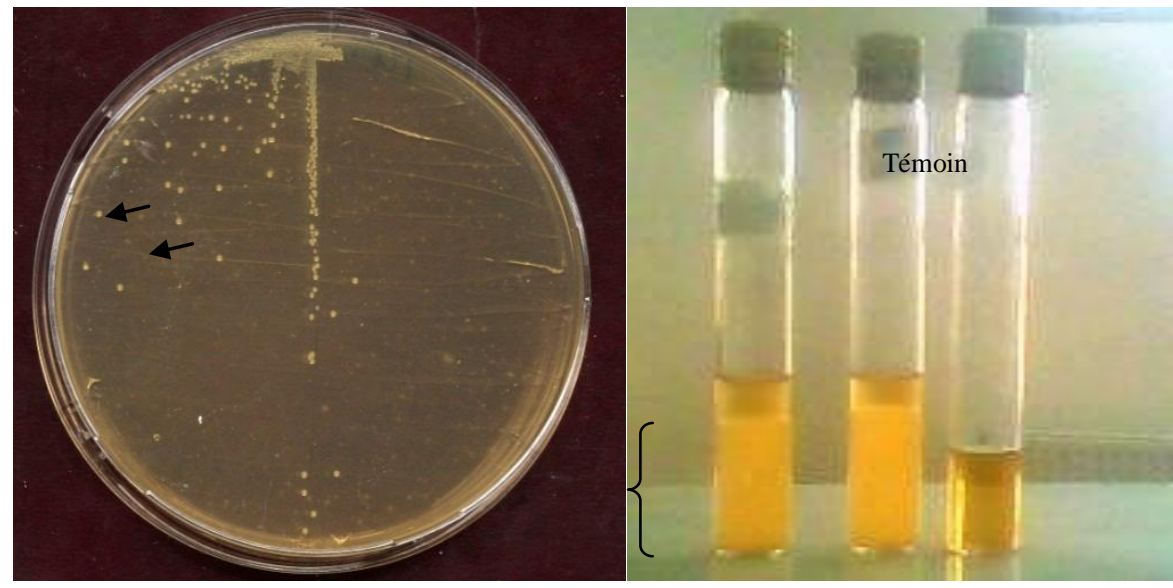

Fig. 1: Appearance of Streptococcus thermophilus colonies after $24 \mathrm{~h}$ incubation at $37^{\circ} \mathrm{C}$ on M17solid medium.
Fig. 2: pure culture of Streptococcus thermophilus in the liquid M17 medium.

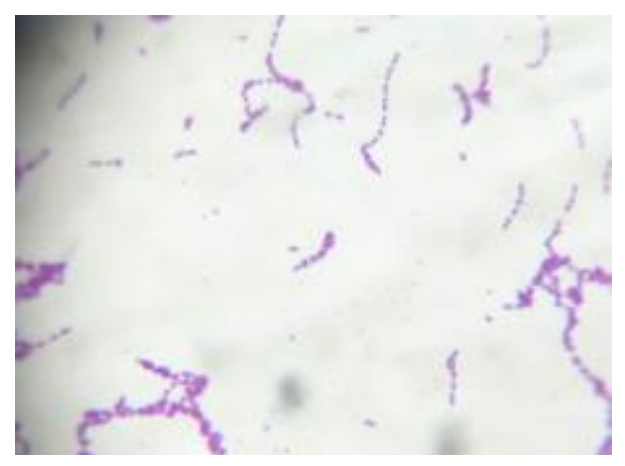

Fig. 3: Microscopic appearance and arrangement of Streptococcus thermophilus after Gram staining (X100).

\subsection{Biochemical characteristics:}

The presence of gaseous bubbles indicates catalase $(+)$, while the absence of gassing during the catalase test indicates that Streptococcus thermophilus are catalase (-). In Fig. 4 we can see that there is no gaseous production, which allows us to note that our microbial strain is the homo-fermenter type. The same findings were observed by some authors for this strain [3, 21].

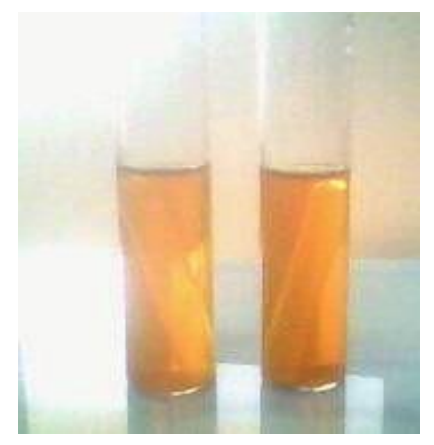


Fig. 4: Fermenter type after 24 hours of incubation.

\subsection{Methylene blue biosorption kinetics:}

The results of the methylene blue biosorption kinetics on the clay complex, shown in Fig. 5, show a rapid fixation of the dye, regardless of $\mathrm{C}_{0}$. The sorption equilibrium is almost reached after 20 minutes of contact, with a rate of elimination after one hour, depending on the initial concentration, and varying between 88 and $96 \%$. Work on the removal of methylene blue by Maghnia clay purified by sedimentation has shown that the rate (R) varies with the initial concentration of the dye, between 84 and $89 \%$ and the balance of adsorption starts during the first five minutes of contact [2]. Similarly, the natural clay of some parts of Morocco, treated by decantation, removes about $90 \%$ of the cationic dyes after a contact time of 5 to 10 minutes [22]. The biomass of Aspergillus niger modified in the presence of formaldehyde and formic acid, removes methylene blue with a rate of 98\% [9]. This indicates that there is a practical interest in the development of the biosorbent complex (clay-biomass), to modify the fixing sites, which allows increasing the rate of removal of dyes.

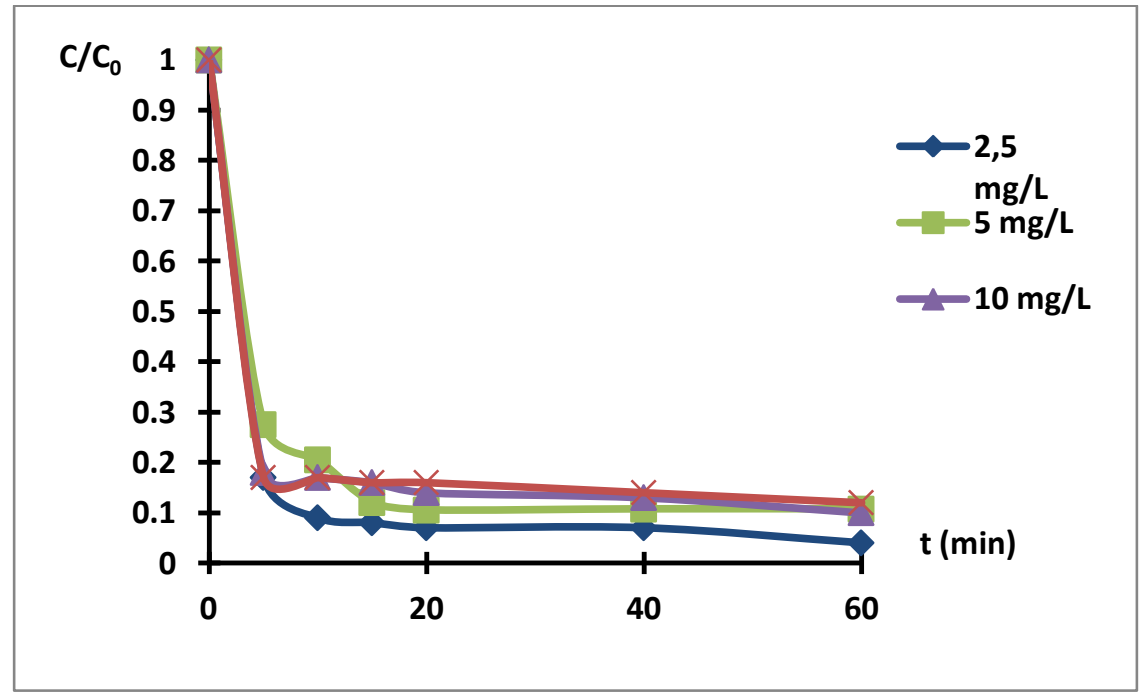

Fig. 5: Methylene blue biosorption kinetics on the clay complex.

Application to experimental results, kinetic models, Lagergren (1st order), Ho and Mc Kay (2nd order) and Weber and Morris (intra-particular diffusion), in their linear forms, Eq. (5), (6) and (7) respectively [2], shows good representativeness of the kinetic model of Ho and Mc Kay for the experimental values found, as shown in Fig. 6, with a good correlation coefficient $\mathrm{R}^{2}$ and a small relative error $\varepsilon$ (\%) (Eq. (8)) [23], which do not exceed 2\%, as shown in Table 2 of the parameters, calculated from the Eq. of the models used. It should also be noted that the intra-particulate diffusion model gives a good correlation beyond an initial BM concentration of $10 \mathrm{mg} / \mathrm{L}$, indicating the formation of a limit layer of dye around the biosorbent, more than $80 \%$ of the quantity adsorbed to equilibrium. Besides, some studies have cited that the kinetic model of Ho and Mc Kay better represents their experimental results, the kinetics of fixing a cationic dye on clays [2, 22] and the biomass of Aspergillus niger [11].

$$
\begin{gathered}
\log \left(\mathbf{q}_{\mathrm{e}}-\mathbf{q}_{\mathrm{t}}\right)=\log \left(\mathbf{q}_{\mathrm{e}}\right)-\frac{\mathbf{k}_{1}}{2,303} \mathbf{t} \\
\frac{\mathbf{t}}{\mathbf{q}_{\mathrm{t}}}=\frac{1}{\mathbf{k}_{2} \cdot \mathbf{q}_{\mathrm{e}}^{2}}+\frac{\mathrm{t}}{\mathbf{q}_{\mathrm{e}}} \\
\mathbf{q}_{\mathrm{t}}=\mathbf{k}_{\mathrm{i}} \cdot \sqrt{\mathbf{t}}+\mathrm{I} \\
\varepsilon(\%)=\frac{100}{N} \sum_{1}^{N} \frac{\left|\left(q_{e, i}\right)_{c a l}-\left(q_{e, i}\right)_{\text {exp }}\right|}{\left(q_{e, i}\right)_{\text {exp }}}
\end{gathered}
$$

Note that $\mathrm{q}_{\mathrm{t}}$ and $\mathrm{q}_{\mathrm{e}}$ are the amounts in blue of methylene adsorbed at the time $\mathrm{t}$ and at equilibrium, respectively. $\mathrm{k}_{1}, \mathrm{k}_{2}$ and $\mathrm{k}_{\mathrm{i}}$ are respectively the first order, second order and intra-particulate rate constants. I is the quantity of adsorbed methylene blue depending on the thickness of the boundary layer formed on the biosorbent. $\left(\mathrm{q}_{\mathrm{e}, \mathrm{i}}\right)_{\exp }$ and $\left(\mathrm{q}_{\mathrm{e}, \mathrm{i}}\right)_{\mathrm{cal}}$ are the biosorbed quantities in BM equilibrium at the concentration i, respectively experimental and calculated by the kinetic model, and where $\mathrm{N}$ is the number of tests. 


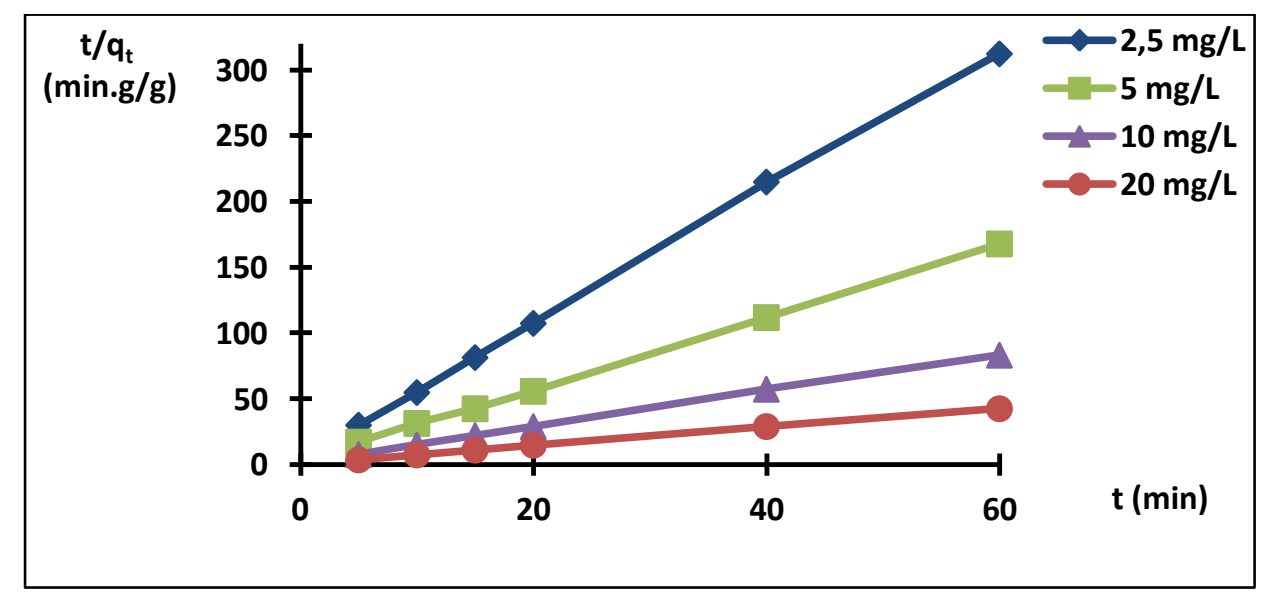

Fig. 6: Application of the Ho and Mc Kay kinetic model.

Table 2: Kinetic model parameters based on initial BM concentration.

\begin{tabular}{|c|c|c|c|c|c|}
\hline & $\mathrm{C}_{0}(\mathrm{mg} / \mathrm{L})$ & 2,5 & 5 & 10 & 20 \\
\hline \multirow{5}{*}{ 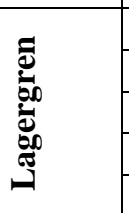 } & $\left(\mathrm{q}_{\mathrm{e}}\right)_{\exp }(\mathrm{mg} / \mathrm{g})$ & 192 & 358 & 720 & 1408 \\
\hline & $\left(\mathrm{q}_{\mathrm{e}}\right)_{\mathrm{cal}}(\mathrm{mg} / \mathrm{g})$ & 22 & 0,03 & 127 & 197 \\
\hline & $\varepsilon(\%)$ & 88,5 & 99,99 & 82,4 & 86,01 \\
\hline & $\mathrm{k}_{1}\left(\min ^{-1}\right)$ & 1 & 0,007 & 0,069 & 0,074 \\
\hline & $\mathrm{R}^{2}$ & 0,5842 & 0,0001 & 0,8516 & 0,8326 \\
\hline \multirow{5}{*}{ 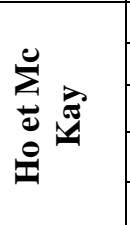 } & $\mathrm{q}_{\mathrm{e}(\exp )}(\mathrm{mg} / \mathrm{g})$ & 192 & 358 & 720 & 1408 \\
\hline & $\mathrm{q}_{\mathrm{e}(\mathrm{cal})}(\mathrm{mg} / \mathrm{g})$ & 193 & 364 & 725 & 1416 \\
\hline & $\varepsilon(\%)$ & 0,5 & 1,7 & 0,7 & 0,6 \\
\hline & $\mathrm{k}_{2}\left(\mathrm{~g} \cdot \mathrm{g}^{-1} \cdot \min ^{-1}\right)$ & 6,3 & 2,9 & 1,4 & 0,96 \\
\hline & $\mathrm{R}^{2}$ & 0,9996 & 0,9996 & 0,9995 & 0,9997 \\
\hline \multirow{3}{*}{ 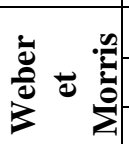 } & $\mathrm{I}(\mathrm{mg} / \mathrm{g})$ & 1 & 290 & 630 & 1285 \\
\hline & $\mathrm{k}_{\mathrm{i}}\left(\mathrm{mg} \cdot \mathrm{g}^{-1} \cdot \mathrm{min}^{-1 / 2}\right)$ & 1 & 10,6 & 11,3 & 15 \\
\hline & $\mathrm{R}^{2}$ & 1 & 0,5844 & 0,9644 & 0,9522 \\
\hline
\end{tabular}

\subsection{Methylene blue biosorption isotherm:}

The use of equilibrium isotherm models [24], Henry Eq. (9), Langmuir and Freundlich, Eq. (10) and (11) respectively in their linear forms, allows to know which is best suited to the experimental values found. Fig. 7 and 8, together with the parameter values presented in Table 3, show that the Henry and Freundlich models show a good correlation with the experimental data, while the Langmuir model is much less so. This is probably due, on the one hand, to the fact that the experimental concentrations used are low and, on the other hand, that the BM biosorption forms a poly-layer on the surface of the biosorbent, which can confirm the formation of a boundary layer around the particles of the adsorbent complex. Adsorption is considered good since $1<$ $\mathrm{n}<10[2]$.

$$
\begin{gathered}
\mathbf{q}_{\mathrm{e}}=\mathbf{k}_{\mathrm{H}} \cdot \mathrm{C}_{e} \\
\frac{c_{e}}{\mathbf{q}_{\mathrm{e}}}=\frac{1}{\mathrm{~b} \cdot \mathrm{q}_{m}}+\frac{c_{e}}{\mathbf{q}_{\mathrm{m}}} \\
\log \left(\mathbf{q}_{\mathrm{e}}\right)=\frac{1}{\mathrm{n}} \log \left(\mathrm{C}_{\mathrm{e}}\right)+\log \left(\mathbf{k}_{\mathrm{F}}\right)
\end{gathered}
$$

Where $\mathrm{q}_{\mathrm{m}}$ is the maximum adsorbed methylene blue amount. $\mathrm{K}_{\mathrm{H}}$ and $\mathrm{K}_{\mathrm{F}}$ are Henry and Freundlich constants, respectively. $\mathrm{b}$ is Langmuir constant, which takes into account the affinity of the adsorption sites and the energy put into play. $\mathrm{n}$ is Freundlich constant, depending on the nature of the adsorbate-adsorbent couple [2]. 


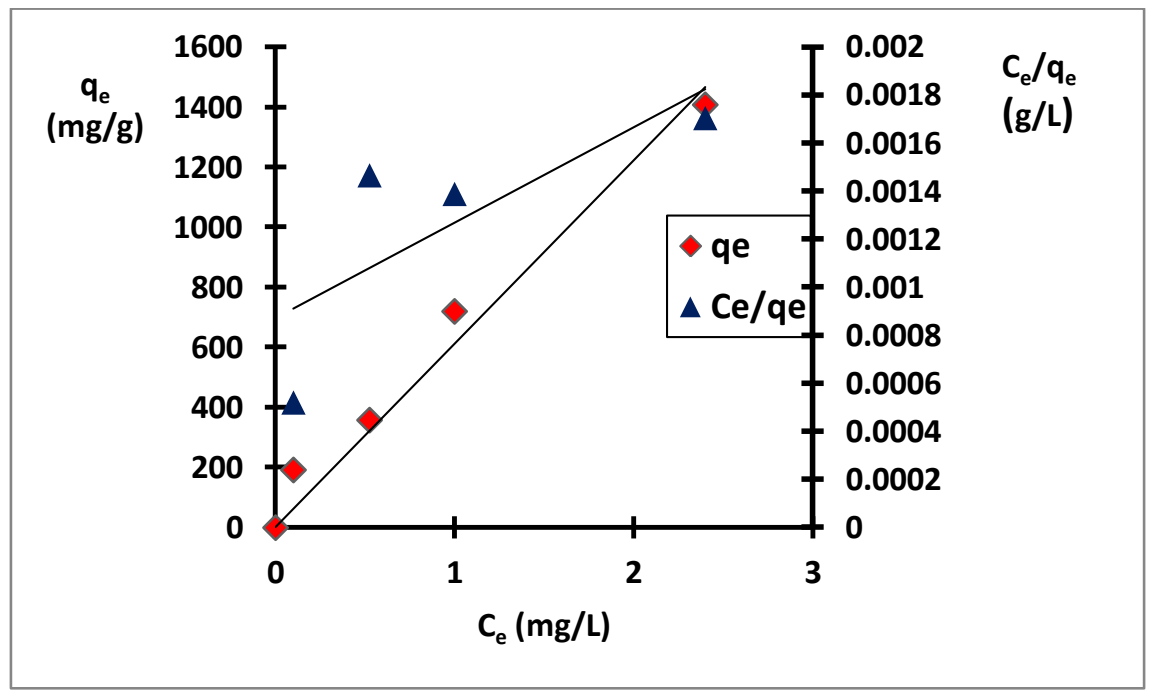

Fig. 7: Application of Henry and Langmuir equilibrium isotherm models.

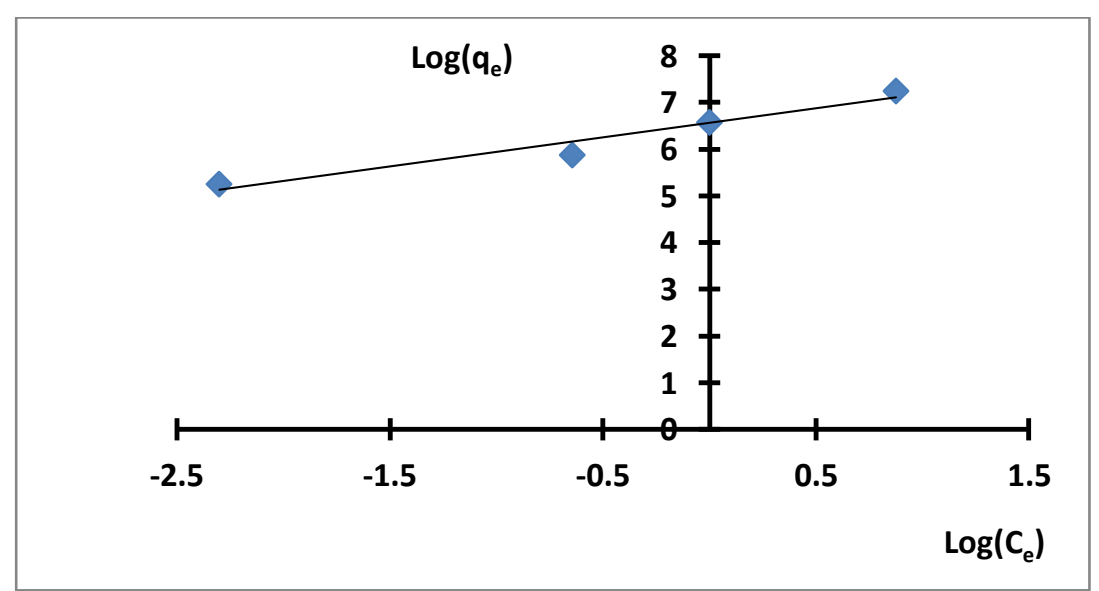

Fig. 8: Application of Freundlich equilibrium isotherm model.

Table 3: Parameters of equilibrium isotherm models.

\begin{tabular}{|c|c|c|c|c|c|}
\hline \multirow{5}{*}{$\stackrel{\vec{\Xi}}{\underline{\Xi}}$} & $\left(\mathrm{q}_{\mathrm{e}}\right)_{\exp }(\mathrm{mg} / \mathrm{g})$ & 192 & 358 & 720 & 1408 \\
\hline & $\left(\mathrm{q}_{\mathrm{e}}\right)_{\mathrm{cal}}(\mathrm{mg} / \mathrm{g})$ & 61 & 321 & 611 & 1467 \\
\hline & $\varepsilon(\%)$ & \multicolumn{4}{|c|}{24,5} \\
\hline & $\mathrm{k}_{\mathrm{H}}\left(\mathrm{L} . \mathrm{g}^{-1}\right)$ & \multicolumn{4}{|c|}{611,2} \\
\hline & $\mathrm{R}^{2}$ & \multicolumn{4}{|c|}{0,9725} \\
\hline \multirow{6}{*}{ 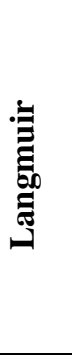 } & $\mathrm{q}_{\mathrm{e}(\exp )}(\mathrm{mg} / \mathrm{g})$ & 192 & 358 & 720 & 1408 \\
\hline & $\mathrm{q}_{\mathrm{e}(\mathrm{cal})}(\mathrm{mg} / \mathrm{g})$ & 105 & 469 & 764 & 1284 \\
\hline & $\varepsilon(\%)$ & \multicolumn{4}{|c|}{22,8} \\
\hline & $\mathrm{q}_{\mathrm{m}}(\mathrm{mg} / \mathrm{g})$ & \multicolumn{4}{|c|}{2500} \\
\hline & b $\left(\mathrm{L} . \mathrm{mg}^{-1}\right)$ & \multicolumn{4}{|c|}{0,44} \\
\hline & $\mathrm{R}^{2}$ & \multicolumn{4}{|c|}{0,5881} \\
\hline$[1$ & $\mathrm{q}_{\mathrm{e}(\exp )}(\mathrm{mg} / \mathrm{g})$ & 192 & 358 & 720 & 1408 \\
\hline
\end{tabular}




\begin{tabular}{|c|c|c|c|c|}
\hline \multirow{2}{*}{$\mathrm{q}_{\mathrm{e}(\mathrm{cal})}(\mathrm{mg} / \mathrm{g})$} & 168 & 474 & 710 & 1227 \\
\cline { 2 - 4 } & $\varepsilon(\%)$ & \multicolumn{3}{|c|}{710} \\
\cline { 2 - 4 } & $\mathrm{k}_{\mathrm{F}}\left(\mathrm{mg}^{(1-1 / \mathrm{n})} \cdot \mathrm{g}^{-1} \cdot \mathrm{L}^{-1 / \mathrm{n}}\right)$ & 1,6 \\
\hline $\mathrm{n}$ & \multicolumn{3}{|c|}{0,948} \\
\hline
\end{tabular}

\section{CONCLUSION}

Streptococcus thermophilus immobilized on suspended clay particles forms an impressive biosorbent complex to treat water polluted by a cationic dye, such as methylene blue. The results obtained show that the microbial strain used and cultivated on M17 agar gives round colonies with cremated white color and small sizes, it is Gram (+), catalase (-) and homo-fermenter. The suspended clay particles purified by sedimentation suggest that Stokes' law has made it possible to verify that they have a size of less than $2 \mu \mathrm{m}$. As for the biosorption of methylene blue on the developed biosorbent complex, the results show a rapid removal of this dye, the sorption balance is almost reached after 20 minutes of contact with a removal rate of one hour, varying between 88 $\%$ and $96 \%$ depending on the initial concentration. The kinetic modelling of the experimental data indicates that they follow the kinetic model of Ho and Mc Kay with a correlation coefficient close to 1. With regards to the diffusion model, it shows the existence of a boundary layer formed around the biosorbent. Moreover, the experimental data are best represented by Henry and Freundlich's equilibrium isotherms, this is probably due to the low concentrations used and the formation of a poly-layer on the surface of the adsorbent complex. It is therefore interesting to use this biosorbent based on the immobilization of Streptococcus thermophilus on clay particles of suspended Maghnia, to treat water polluted by cationic dyes.

\section{REFERENCES}

1. Kausar, A., M. Iqbal, A. Javed, K. Aftab, Z-i-H. Nazli, H-N. Bhatti and S. Nouren, 2018. Dyes adsorption using clay and modified clay: A review. Journal of Molecular Liquids, $256: 395-407$.

2. Hadj Said, A., M-H. Manero and E-H. Belarbi, 2014. Removal of cationic dye from the aqueous solutions by using the naturel clay of Maghnia (Algeria). Desalination and Water Treatment, 52: 6673-6683.

3. Moulay, M., A. Hadj Said, L. Hocine and M. Kihal, 2016. Immobilization Of Lactic Acid Bacteria On Bentonite Clay Particles of Maghnia Region West-Algerian. Advances in Environmental Biology, 10(10) October: 33-39.

4. Haghollahi, A., M-H. Fazaelipoor and M. Schaffie, 2016. The effect of soil type on the bioremediation of petroleum contaminated soils. Journal of Environmental Management, $180:$ 197-201.

5. Parot, S., 2007. Biofilms électroactifs : Formation, Caractérisation et mécanismes. Thèse de docteur de l'Institut National Polytechnique de Toulouse (France).

6. Ibrahim, M., R. M.Y. Briandet, A. Mistou, J. Chrétien, Tremblay et S. Kulakauskas, 2004. Immobilisation des Lactocoques. Lait., (84) : 103-114.

7. Weng, C.H. and Y.F. Pan, 2007. Adsorption of cationic dye (methylene blue) onto spent activated clay, J. Hazard. Mater. 144: 355-362.

8. Unuabonah, E-I., C-G. Ugwuja, M-O. Omorogie, A. Adewuyi and N-A. Oladoja, 2018. Clays for Efficient Disinfection of Bacteria in Water. Applied Clay Science, 151: 211-223.

9. Fu, Y. and T. Viraraghavan 2002. Dye biosorption sites in Aspergillus niger. Bioresource Technology, $82: 139-145$.

10. Prigione, V., V. Tigini, C. Pezzella, A. Anastasi, G. Sannia and G-C. Varese, 2008. Decolourisation and detoxification of textile effluents by fungal biosorption. Water research, 42: 2911-2920.

11. Kim, Su Y., Mi R. Jin, C. Ho Chung, Y-S. Yun, K-Y. Jahng and K-Y Yu, 2015. Biosorption of cationic basic dye and cadmium by the novel biosorbent Bacillus catenulatus JB-022 strain. Journal of Bioscience and Bioengineering 119 (4): 433439.

12. Kosseva, M-R., P-S. Panesar, G. Kaur and J-F. Kennedy, 2009. Use of immobilised biocatalysts in the processing of cheese whey. International Journal of Biological Macromolecules 45 : 437-447.

13. Bouras, O., 2003. Propriétés adsorbantes d'argiles pontées organophiles: synthèse et caractérisation. PhD study, University of Limoges, France.

14. Moulay, M., K. Benlahcen, H. Aggad and M. Kihal, 2013. Diversity And Technological Properties Of Predominant Lactic Acid Bacteria Isolated From Algerian Raw Goat's Milk. Adv. in Environ. Biology, 7(6): 999-1007.

15. Larpent, J.P., 1993. Les ferments microbiens dans les industries agro-Alimentaires (Produits laitiers et carnés). Apria, Paris, (30): $331-340$.

16. Bourgeois, C.M et J.P. Larpent, 1996. Microbiologie alimentaire. Tome 2. Aliments fermentés et fermentation alimentaire. Ed. Tec et Doc Lavoisier, Paris. 
17. Nardin, M. et E. Papirer, 1985. Méthode de Mesure de la Taille Moyenne d'Agglomerats de Particules. Powder Technology, (44) : $141-143$.

18. Shichi, T. and K. Takagi, 2000. Clay minerals as photochemical reaction fields. Journal of Photochemistry and Photobiology C: Photochemistry Reviews, (1): 113-130.

19. Larpent-Gourgaud, M. et J.P. Larpent, 1997. Mémento technique de microbiologie. Ed. Tec et Doc Lavoisier, Paris.

20. Novel, G., 1993. Microorganismes d'intérêt industriel. Ed. Tec et Doc Lavoisier, Paris.

21. Delarras, C., 2007. Microbiologie pratique pour laboratoire d'analyses ou de contrôle sanitaire. Ed. Tec et doc, Lavoisier, Paris.

22. Elmoubarki, R., F.Z. Mahjoubi, H. Tounsadi, J. Moustadraf, M. Abdennouri, A. Zouhri, A. El Albani and N. Barka, 2015. Adsorption of textile dyes on raw and decanted Moroccan clays: Kinetics, equilibrium and thermodynamics. Water Resources and Industry, (9) : 16-29.

23. Gulnaz, O., A. Kaya, F. Matyar and B. Arikan, 2004. Sorption of basic dyes from aqueous solution by activated sludge, J. Hazard. Mater. (B108): 183-188.

24. Hao, Y-F., L-G. Yan, H-G. Yu, K. Yang, S-G. Yu, R-R. Shan and B. Du, 2014. Comparative study on adsorption of basic and acid dyes by hydroxy-aluminum pillared bentonite. Journal of Molecular Liquids 199 : 202-207. 